\title{
Analisis Unjuk Kerja Convolutional Code pada Sistem MIMO MC-DSSS Melalui Kanal Rayleigh Fading
}

\author{
Kadek Agus Mahabojana Dwi Prayoga ${ }^{1}$, N.M. Ary Esta Dewi W' ${ }^{2}$, I.G.A.K Diafari Djuni ${ }^{3}$
}

\begin{abstract}
The combination of MIMO (multiple input multiple output), OFDM (orthogonal frequency division multiplexing), and spread spectrum and their channel coding technique is expected to reduce the effects of fading and the error that occurred. This study is aimed to compare the performance of MIMO MC-DSSS (multi carrier-direct sequence spread spectrum) uncoded or without channel coding and MIMO MCDSSS Convolutional Code or convolutional channel coding through channels Rayleigh Fading in terms of value and graph BER (bit error rate) vs. Eb/No (energy per bit to noise power spectral density ratio). This study used simulation using Matlab R2015a. The results of the simulation obtained MIMO system performance MC-DSSS with Convolutional Code had better results than MIMO MC-DSSS Uncode. In the transmission channel Rayleigh Fading to peak at 10-3 BER value in MIMO MC-DSSS system with Convolutional Code required Eb / No of $7 \mathrm{~dB}$. While the MC-DSSS MIMO systems required Eb / No -3 dB.
\end{abstract}

Intisari- Kombinasi antara sistem MIMO (multiple input multiple output), OFDM (orthogonal frequency division multiplexing), dan spread spectrum serta adanya teknik pengkodean kanal mampu mengurangi efek fading dan error yang terjadi. Penelitian ini bertujuan untuk mengetahui perbandingan performansi dari sistem MIMO MC-DSSS (multi carrier-direct sequence spread spectrum) Uncoded atau tanpa pengkodean kanal dan MIMO MC-DSSS Convolutional Code atau dengan pengkodean kanal Convolutional yang melalui kanal Rayleigh Fading, ditinjau dari nilai dan grafik BER (bit error rate) berbanding $\mathrm{Eb} / \mathrm{No}$ (energy per bit to noise power spectral density ratio). Penelitian ini menggunakan metode simulasi dengan menggunakan program Matlab R2015a. Hasil dari simulasi didapat unjuk kerja sistem MIMO MC-DSSS dengan Convolutional Code memiliki hasil yang lebih baik dari MIMO MC-DSSS. Pada kanal transmisi Rayleigh Fading untuk mencapi nilai BER sebesar 10-3 pada sistem MIMO MC-DSSS dengan Convolutional Code dibutuhkan Eb/No sebesar -7 dB. Sedangkan pada sistem MIMO MC-DSSS dibutuhkan Eb/No sebesar -3 dB.

Kata Kunci- MIMO, OFDM, Spread Spectrum, MC-DSSS, Convolutional Code, Rayleigh Fading.

\footnotetext{
${ }^{1}$ Mahasiswa, Jurusan Teknik Elektro dan Komputer Fakultas Teknik Universitas Udayana, Jln. Kampus Bukit Jimbaran 80361 INDONESIA (tlp: 0361-703315; fax: 0361-4321; e-mail: mahabojanadwi@yahoo.co.id)

2, 3 Dosen, Jurusan Teknik Elektro dan Komputer Fakultas Teknik Universitas Udayana, Jln. Jalan Kampus Bukit Jimbaran 80361 INDONESIA (telp: 0361-703315; fax: 0361-4321; e-mail: dewi.wirastuti@ee.unud.ac.id)
}

\section{PENDAHULUAN}

Kombinasi teknologi MIMO dan MC-DSSS merupakan salah satu teknologi yang digunakan dalam mewujudkan layanan komunikasi yang cepat dan baik pada komunikasi wireless

Multi carrier direct sequence spread spectrum menawarkan efisiensi spectral, ketahanan terhadapat gangguan dan fleksibelitas [1]. MC-DSSS dikenal juga sebagai OFDMDSSS (orthogonal frequency division multiplexing - direct sequence spread spectrum).

OFDM merupakan teknik modulasi multicarrier, dimana antar subcarrier satu dengan yang lain saling orthogonal. Karena sifat orthogonal ini, maka antar subcarrier dibuat overlapping tanpa menimbulkan efek ICI (inter carrier interference). Dengan multiplexing subcarrier yang dilakukan secara overlap tersebut tentu saja dapat menghemat bandwidth. Proses yang dilakukan sama dengan teknik modulasi multicarrier, yang membedakan hanya pada penggunaan subcarrier yang saling orthogonal pada masingmasing subkanal [2].

Masalah gangguan pada kanal atau multipath fading pada jaringan wireless dapat diatasi dengan sistem MIMO (Multiple Input Multiple Output). Hal tersebut bertujuan untuk menjadikan sinyal pantulan sebagai penguat sinyal utama sehingga saling mendukung atau tidak saling menggagalkan [3]. Prinsip kerja MIMO adalah memperbanyak sinyal informasi yang dipancarkan untuk meningkatkan kemampuan komunikasi dan mengurangi error yang dapat terjadi akibat kanal transmisi.

Untuk mengurangi noise dalam teknologi telekomunikasi wireless, perlu adanya sebuah teknik pengkodean kanal untuk mendapat nilai Quality of Service (QoS) yang diharapkan [4]. Kombinasi MIMO dengan MC-DSSS menggunakan pengkodean kanal Convolutional diharapkan dapat menghasilkan sistem yang lebih baik dengan menggabungkan keunggulan masing-masing sistem.

Jadi pada penelitian ini, akan melakukan simulasi unjuk kerja dari sistem MIMO MC-DSSS Uncode dan MIMO MCDSSS dengan Convolutional Code pada kanal AWGN dan Rayleigh Fading. Kemudian membandingkan unjuk kerja dari masing-masing sistem untuk mengetahui sistem mana yang memiliki unjuk kerja yang paling baik.

\section{MIMO MC-DSSS CONVOLUTIONAL CODE DAN RAYLEIGH FADING}

\section{A. Direct Sequence Spread Spectrum}

Direct sequence merupakan teknik spread spectrum yang mempunyai data rate yang tinggi. Direct sequence menggunakan kode unik untuk menebarkan sinyal baseband yang akan dimodulasi digital bersama sinyal informasi. Prinsip Kerja DSSS adalah menebarkan sinyal informasi 
sinyal informasi dengan sinyal acak yang dihasilkan oleh pseudo random. Sehingga akan menghasilkan sinyal baru dengan lebar periode sinyal yang sama dengan pseudo noise. Kemudian sinyal tersebut dimodulasi terlebih dahulu sebelum dipancarkan melalui antena [5].

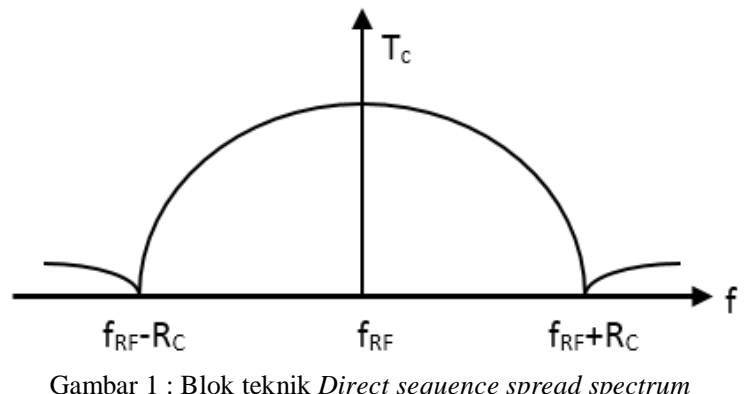

B. OFDM (Orthogonal Frequency Division Multiplexing)

OFDM merupakan teknik transmisi yang menggunakan beberapa buah frekuensi yang saling orthogonal atau tegak lurus. Pada teknik transmisi OFDM data dialirkan ke beberapa subcarrier yang saling orthogonal atau saling overlapping tanpa menimbulkan ICI (inter carrier interference) [6].

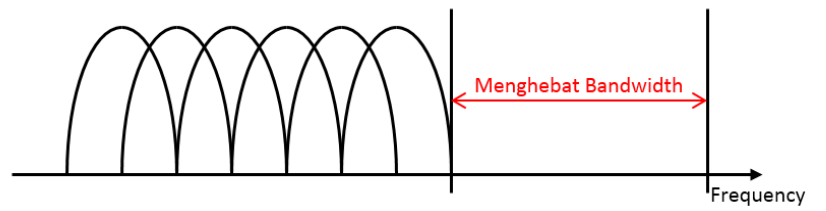

Gambar 2 : Efisiensi bandwidth menggunakan teknik OFDM

Pada Gambar 2 menunjukkan teknik OFDM yang mampu memberikan efisiensi dalam penggunaan bandwidth hingga mencapai 50\% karena teknik OFDM memperbolehkan adanya overlapping tanpa adanya interferensi.

\section{MIMO (Multiple Input Multiple Output)}

MIMO merupakan suatu teknik pada sistem komunikasi wireless yang menggunakan lebih dari satu antena di sisi pengirim $\mathrm{M}$ dan lebih dari satu antena di sisi penerima $\mathrm{N}$, dengan $M \geqslant N$. Setiap antena akan mengirimkan informasi yang berbeda secara independen dan simultan dalam band frekuensi yang sama. Sistem MIMO diharapkan dapat mengurangi fading dan interferensi dari user lain, meningkatkan reliability, meningkatkan throughput tanpa perlu meningkatkan bandwidth, mengurangi daya transmit [7]. Teknik MIMO dapat dilihat pada Gambar3.

\section{Convolutional Code}

Convolutional Code adalah jenis kode yang memiliki perbedaaan mendasar dari block code dimana urutan bit informasi tidak dikelompokkan dalam blok-blok yang berbeda sebelum dikodekan. Proses yang terjadi adalah bit informasi sebagai masukan secara kontinyu di mapping kedalam urutan bit output encoder [8].

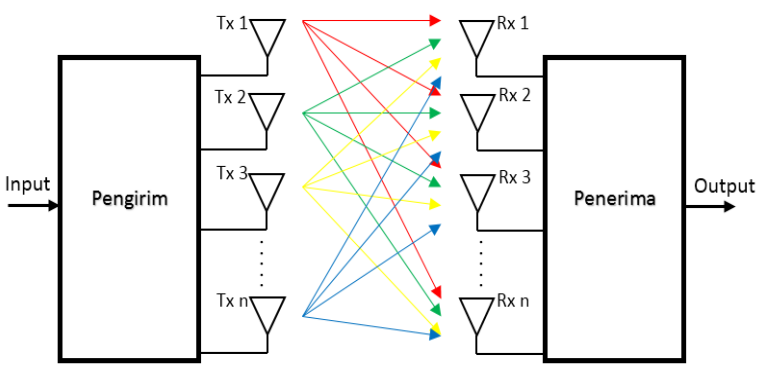

Gambar 3 : Teknik MIMO

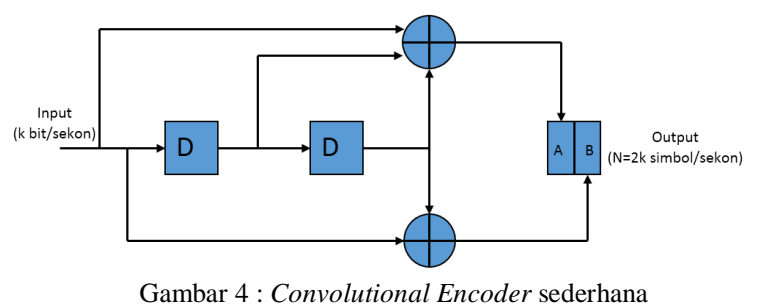

Pada Gambar 4 dapat dilihat encoder tersebut terdirir dari $\mathrm{K}-1$ buah shift register dan $\mathrm{n}$ buah adder modulo-2. Parameter $\mathrm{K}$ dikenal dengan constraint length. Banyaknya bit yang dimasukkan ke dalam shift register encoder dinotasikan dengan $\mathrm{k}$. Laju kode biasanya dinyatakan dengan $\mathrm{k} / \mathrm{n}$. Contoh gambar 2 menunjukkan encoder dengan laju 1/2, yaitu setiap 1 bit yang masuk, dihasilkan 2 bit keluaran (disebut dengan codeword). Generator polynomial didefinisikan sebagai respons impuls terhadap memori register encoder, atau dengan kata lain menggambarkan bagian memori register yang dikoneksikan ke setiap adder.

\section{E. AWGN (Additive White Gaussian Noise)}

AWGN merupakan noise yang berada dan terjadi pada kanal rentang spektrum frekuensi dan merupakan noise thermal yang sifatnya menjumlah [8]. Noise ini terdiri dari seluruh frekuensi dalam spektralnya sebagai cahaya putih yang memiliki rapat spectral daya yang konstan.

\section{F. Flat Fading}

Flat Fading dapat terjadi apabila kanal mempunyai penguatan yang konstan dan tanggapan fase linier dengan bandwidth yang lebih lebar dibandingkan dengan bandwidth sinyal yang ditransmisikan. Pada kondisi ini, level sinyal yang diterima berubah terhadap waktu yang disebabkan oleh multipath [7]. Karakteristik kanal flat fading dapat dilihat pada Gambar 5. 


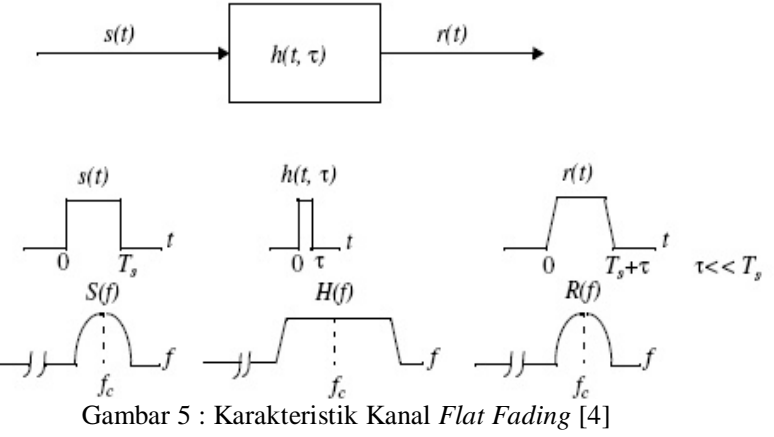

Pada umumnya distribusi amplitudo pada flat fading mengikuti distribusi Rayleigh. Model kanal flat fading Rayleigh mengasumsikan bahwa amplitudo dari kanal bervariasi terhadap waktu sesuai dengan distribusi Rayleigh. Kanal flat fading mempunyai kriteria seperti persamaan 1 berikut [7].

TS $>\sigma \tau$

Dengan, TS adalah periode simbol, dan or adalah rms delay spread.

\section{G. Distrubusi Rayleigh}

Distribusi Rayleigh biasa digunakan untuk menjelaskan perubahan waktu dari selubung sinyal flat fading yang diterima, atau selubung dari satu komponen multipath telah diasumsikan sebelumnya menjadi distribusi Rayleigh.

$p(r)=\left\{\begin{array}{cc}\frac{r}{\sigma^{2}} \exp \left(\frac{r^{2}}{2 \sigma^{2}}\right) & (0 \leq r \leq \infty) \\ 0 & (r<0)\end{array}\right.$

Distribusi Rayleigh digunakan untuk mendeskripsikan keadaan pada suatu kanal. Distribusi Rayleigh memiliki fungsi kerapatan probabilitas atau probability density function (pdf) pada persamaan 2 .

\section{Metode PENELITIAN}

Penelitian ini menggunakan metode simulasi dimana bertuuan untuk mengetahui unjuk kerja dari Convolutional code pada sistem MIMO MC-DSSS melalui kanal Rayleigh Fading. Simulasi yang akan dilakukan pertama yaitu dengan menjalankan sistem MIMO MC-DSSS tanpa menggunakan pengkodean kanal, kemudian menjalankan simulasi sistem MIMO MC-DSSS yang menggunakan pengkodean kanal Convolutional. Selanjutnya membandingkan unjuk kerja dari kedua sistem tersebut.

\section{A. Alur Penelitian}

Tahapan penelitian yang dilakukan dimulai dengan melakukan pomodelan sistem dalam software Matlab R2015a. Hasil dari simulasi yang dilakukan pada software Matlab R2015a berupa grafik dan nilai BER berbanding Eb/No yang kemudian akan analisis. Alur penelitian dapat dilihat pada Gambar 6.

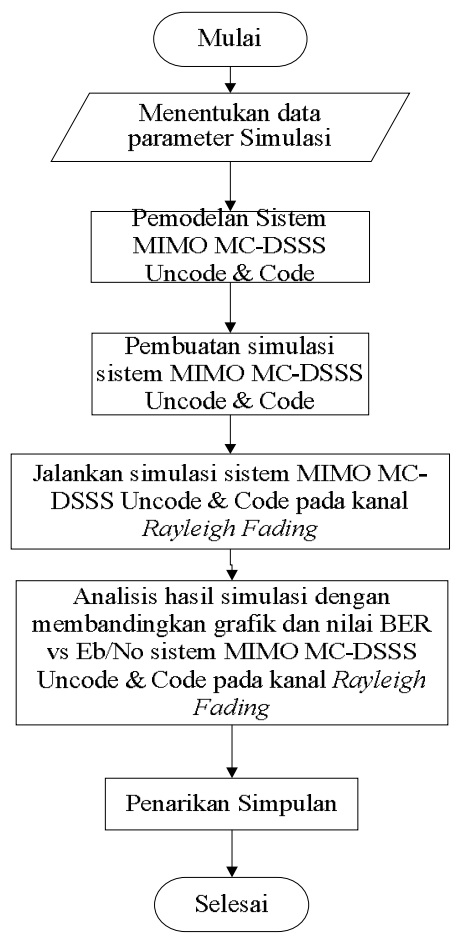

Gambar 6 : Alur Penelitian

\section{B. Parameter Simulasi}

Adapun parameter simulasi yang digunakan dalm pemodelan sistem MIMO MC-DSSS Uncode dan sistem MIMO MC-DSSS Code menggunakan teknik pengkodean Convolutional code dapat dilihat pada Tabel 1.

TABEL I

PARAMETER SIMULASI

\begin{tabular}{|c|c|}
\hline Parameter & Nilai yang digunakan \\
\hline Panjang simbol OFDM & 64 \\
\hline Jumlah subcarrier & 52 \\
\hline Jumlah simbol FFT & 64 \\
\hline Tipe modulasi & QPSK \\
\hline Zero Padding & Cyclic prefix \\
\hline Guard interval type & 16 \\
\hline Panjang cyclic prefix & 50 \\
\hline Jumlah bit per OFDM simbol & PN Code \\
\hline Jenis spreading code & 15 \\
\hline Spreading factor & Single user \\
\hline User type & STBC $2 \times 2$ \\
\hline MIMO type & $-10: 1$ : 10 \\
\hline Nilai Eb/No & 65000 bit (random) \\
\hline Jumlah bit yang input & 1/2 bit per simbol \\
\hline Laju kode (R) & Viterbi \\
\hline Constraint Length (K) & \\
\hline Tipe Dekoder & Vit \\
\hline
\end{tabular}

\section{Pemodelan Sistem MIMO MC-DSSS Uncode}

Pada penelitian ini, pemodelan sistem MC-DSSS dikombinasikan dengan teknik MIMO STBC 2x2 pada kanal Rayleigh Fading dapat dilihat pada Gambar 7. 


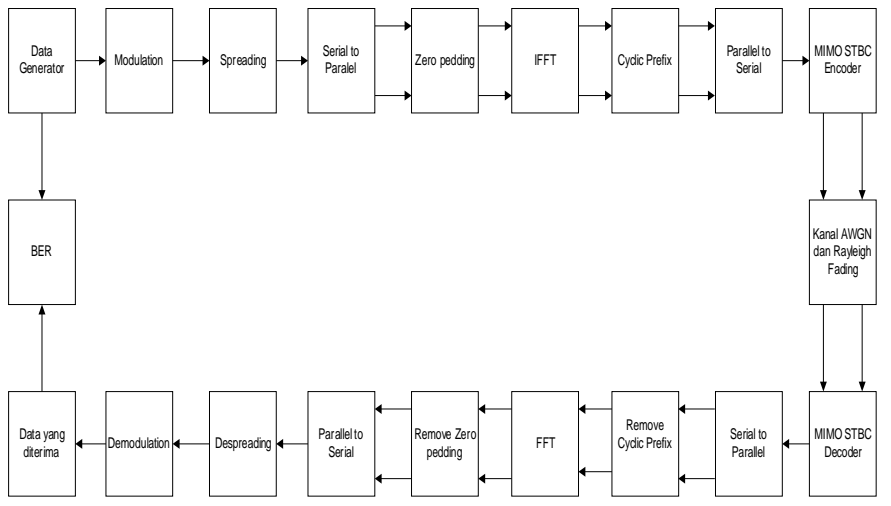

Gambar 7 : Blok Pemodelan Sistem MIMO MC-DSSS Uncode

\section{Pembangkitan Data Generator}

Pembangkitan data masukan dilakukan secara acak (random). Data yang dibangkitkan berjumlah 65.000 bit dalam bentuk biner "1" dan "0" untuk mendekati keadaan transmisi data pada kondisi sesungguhnya.

\section{Pemancar MIMO dan MC-DSSS Uncode}

Pada pemancar MC-DSSS terdapat beberapa blok tahapan dimulai dari blok dimodulasi dimana teknik modulasi yang digunakan yaitu QPSK, namun sebelum dimodulasi harus dilakukan mapping menjadi konstelasi kanal I dan Q untuk menghasilkan 2 bit per simbol untuk dimodulasikan. Hasil modulasi tadi masuk kedalam blok spreading. Dalam blok spreading ini data hasil modulasi yang mengalami proses spreading akan berubah dari bentuk serial ke parallel. Selanjutnya masuk kedalam blok penambahan zero padding. Penambahan zero padding bertujuan untuk menambah durasi sinyal OFDM yang terbentuk. Kemudian blok Inverse Fast Fourier Transform (IFFT) yang bertujuan mengubah dari domain frekuensi ke domain waktu dan untuk menghasilkan frekuensi carrier yang saling orthogonal. Penambahan Guard Interval (GI) pada simulasi ini menggunakan tipe Cyclic Prefix (CP). Penempatan CP disisipkan di depan simbol data masukan yang akan ditrasmisikan. Tujuan dari penambahan GI adalah untuk mencegah terjadinya Inter Symbol Interference (ISI) dan Inter Carrier Interference (ICI) sehingga simulasi dapat berjalan dengan baik. Selanjutnya pada blok encoder STBC memiliki fungsi untuk pengiriman data yang berbentuk serial kedalam kedua antena pengirim (Tx). Adapun pembagian data dalam proses pengiriman menggunakan teknik MIMO STBC 2x2 ini dijabarkan pada Gambar 8 berikut.

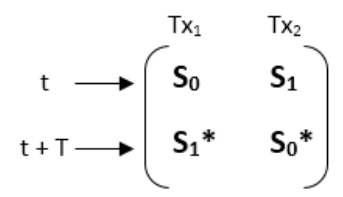

Gambar 8 : Skema Transmisi STBC Alamouti
Dimana S0 dan S1 merupakan simbol sinyal yang dikirim sedangkan $-\mathrm{S} 1^{*}$ dan $\mathrm{S} 0 *$ merupakan bentuk operasi konjugat. Pengiriman sinyal dibagi menjadi $t$ dan $\mathrm{t}+\mathrm{T}$, dimana pada saat $\mathrm{t}$, Tx1 mengirimkan sinyal $\mathrm{S} 0$ dan Tx2 mengirimkan sinyal S1. Kemudian saat $\mathrm{t}+\mathrm{T}$, Tx1 akan mengirimkan sinyal $-\mathrm{S} 1 *$ dan $\mathrm{Tx} 2$ mengirimkan sinyal S0*.

\section{Kanal Transmisi}

Kanal transmisi dalam simulasi ini menggunakan kanal AWGN dan kanal Rayleigh Fading yang ditambahkan dengan noise AWGN.

\section{Penerima MIMO dan MC-DSSS Uncode}

Pada blok MIMO STBC Decoder memiliki fungsi untuk mendekodingkan kembali data yang telah diterima oleh antena penerima. Selanjutnya dilakukan proses combining pada combiner. Pada combiner dilakuakan proses estimasi dari nilai S0 dan S1 yang dikirim dengan combining pada decoder STBC untuk mendapatkan nilai Ŝ0 dan Ŝ. Kemudian dilanjutkan ke proses pendeteksian Maximum Likehood Detection. Pada sisi penerima MC-SS, data dari blok MIMO STBC decoder diubah bentuknya dari serial ke parallel. Setelah itu cyclic prefix yang terdapat di dalam data yang diterima dihilangkan. Selanjutnya adalah proses Fast Fourier Transform (FFT) yang mengubah data diterima dari domain waktu ke domain frekuensi. Blok selanjutnya adalah menghilangkan bit-bit nol zero padding. Setelah itu data akan mengalami proses despreading, dimana dari hasil despreading ini data yang berbentuk parallel akan kembali ke bentuk serial. Setelah itu data akan didemodulasi QPSK. Hasil demodulasi kemudian di demapping untuk mendapatkan bit keluaran.

\section{Perbandingan BER Sistem MIMO MC-DSSS Uncode}

Setelah mendapatkan data keluaran dari sistem MIMO MC-DSSS maka selanjutnya dilakukan perbandingan antara bit yang dikirimkan dan bit yang diterima untuk mendapatkan nilai BER (bit error rate) yang kemudian dibandingkan dengan Eb/No.

\section{Pemodelan Sistem MIMO MC-DSSS Convolutional Code}

Pemodelan sistem MIMO MC-DSSS Code dengan menggunakan teknik pengkodean Convolutional code dimana pemodelannya dapat dilihat pada Gambar 9 yang masingmasing bloknya telah dijelaskan sebelumnya.

Pada pemodelan simulasi sistem MIMO MC-SS Code dengan menggunakan teknik pengkodean Convolutional code terdapat penambahan blok Convolutional encoder pada awal transmisi dan blok Viterbi decoder pada akhir transmisi. 


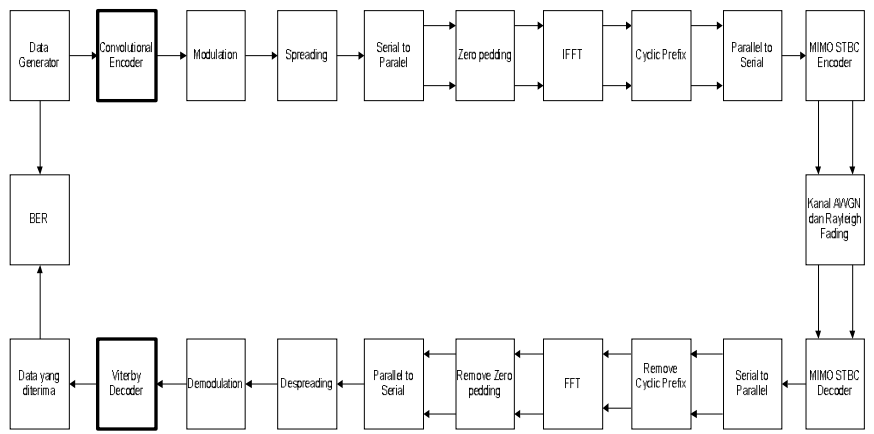

Gambar 9 : Blok Pemodelan Sistem MIMO MC-DSSS dengan Convolutional Code

\section{Convolutional Encoder}

Pada blok encoder, bit-bit keluaran bergantung dari laju kode yang digunakan. Penelitain ini menggunakan laju kode $1 / 2$, jadi setiap 1 bit yang masuk, dihasilkan 2 bit keluaran.

\section{Viterbi Decoder}

Proses dekoding dapat disamakan dengan membandingkan deretan bit yang diterima dengan semua kemungkinan bit terkode, dari proses perbandingan tersebut akan dipilih bit yang paling mirip antara deretan bit yang diterima dengan kemungkinan deretan bit-bit yang ada. Pada blok ini hasil demodulasi akan dikodekan kembali menggunakan algoritma Viterbi mencari kemungkinan bit yang paling mirip, sehingga mendapatkan bit keluaran.

\section{HASIL DAN PEMBAHASAN}

\section{A. Hasil Simulasi Sistem MIMO MC-DSSS Uncode}

Simulasi sistem MIMO MC-DSSS Uncode dilakukan mengikuti pemodelan sistem MIMO MC-DSSS pada Gambar 7. Simulasi ini bertujuan untuk mengetahui unjuk kerja dari sistem MIMO MC-DSSS Uncode pada kanal transmisi Rayleigh Fading berdasarkan parameter BER vs Eb/No. Grafik unjuk kerja sistem MIMO MC-DSSS pada kanal AWGN dan Rayleigh Fading ditunjukan pada Gambar 10.

Berdasarkan pada Gambar 10, pada sistem MIMO MCDSSS Uncode untuk mencapi nilai BER sebesar $10^{-3}$ pada kanal transmisi AWGN dibutuhkan Eb/No sebesar $-4 \mathrm{~dB}$. Sedangkan pada kanal transmisi Rayleigh Fading dibutuhkan $\mathrm{Eb} /$ No sebesar $-3 \mathrm{~dB}$.

Dari Gambar 10 dapat dilihat bahwa pada kanal transmisi AWGN memiliki nilai BER lebih kecil dari kanal transmisi Rayleigh Fading. Hal itu karena pemodelan AWGN tidak melewatkan data yang dikirimkan pada sebuah kanal atau saluran komunikasi yang memiliki efek fading, melainkan hanya menambahkan pengaruh noise AWGN dalam proses transmisi antara pengirim dan penerima.

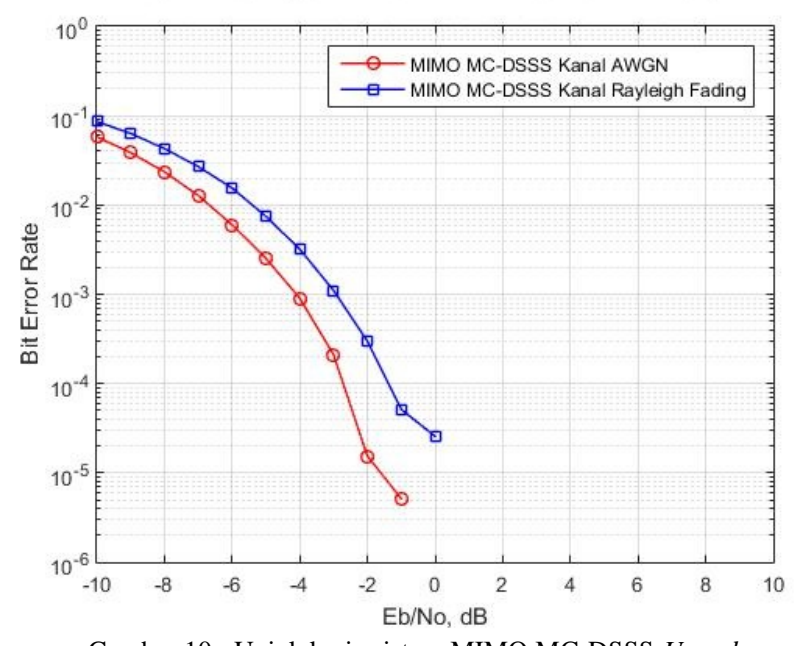

Gambar 10 : Unjuk kerja sistem MIMO MC-DSSS Uncode

\section{B. Hasil Simulasi Sistem MIMO MC-DSSS dengan Convolutional Code}

Simulasi sistem MIMO MC-DSSS dengan Convolutional Code dilakukan mengikuti pemodelan sistem MIMO MCDSSS Convolutional Code pada Gambar 9. Simulasi ini bertujuan untuk mengetahui unjuk kerja dari sistem MIMO MC-DSSS dengan menggunakan pengkodean kanal Convolutional pada kanal transmisi Rayleigh Fading berdasarkan parameter BER vs Eb/No. Grafik unjuk kerja sistem MIMO MC-DSSS dengan Convolutional Code pada kanal transmisi AWGN dan Rayleigh Fading ditunjukan pada Gambar 11.

Berdasarkan pada Gambar 11, pada sistem MIMO MCDSSS dengan Convolutional Code untuk mencapi nilai BER sebesar $10^{-3}$ pada kanal transmisi AWGN dibutuhkan Eb/No sebesar $-8 \mathrm{~dB}$. Sedangkan pada kanal transmisi Rayleigh Fading dibutuhkan Eb/No sebesar $-7 \mathrm{~dB}$.

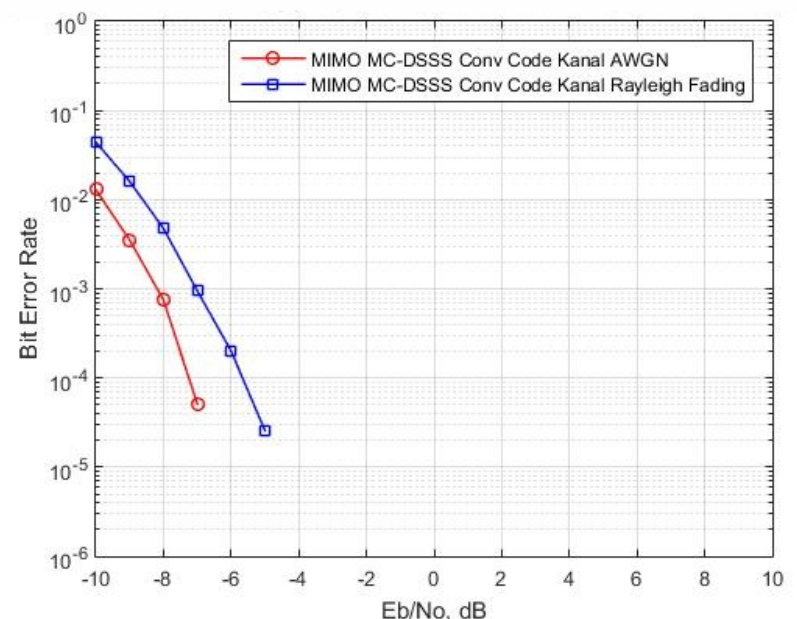

Gambar 11 : Unjuk kerja sistem MIMO MC-DSSS dengan Convolutional Code

Dapat dilihat pada Gambar 11 kanal transmisi Rayleigh Fading memiliki nilai BER lebih besar dari kanal transmisi 
AWGN. Hal ini dikarenakan pada kanal transmisi Rayleigh Fading data yang dikirimkan tidak hanya melewati kanal atau saluran komunikasi yang memiliki efek fading saja, melainkan ada penambahan noise AWGN dalam proses transmisi antara pengirim dan penerima.

\section{Perbandingan Unjuk Kerja Sistem MIMO MC-DSSS Uncode dengan MIMO MC-DSSS Convolutional Code}

Perbandingan antara hasil simulasi sistem MIMO MCDSSS Uncode dan MIMO MC-DSSS dengan Convolutional Code berdasarkan parameter BER vs Eb/No. Grafik dari perbandingan sistem MIMO MC-DSSS Uncode dan MIMO MC-DSSS dengan Convolutional Code ditunjukan pada Gambar 12.

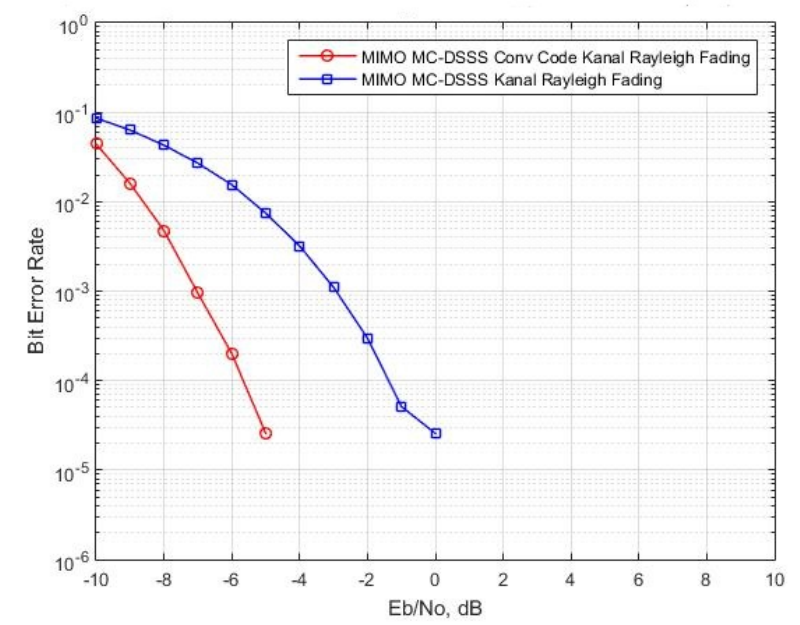

Gambar 12 : Perbandingan MIMO MC-DSSS Uncode dengan MIMO MCDSSS Convolutional Code

Berdasarkan pada Gambar 12, pada kanal transmisi Rayleigh Fading untuk mencapi nilai BER sebesar $10^{-3}$ pada sistem MIMO MC-DSSS dengan Convolutional Code dibutuhkan Eb/No sebesar $-7 \mathrm{~dB}$. Sedangkan pada sistem MIMO MC-DSSS Uncode dibutuhkan Eb/No sebesar -3 dB.

Hasil perbandingan simulasi didapatkan bahwa kinerja sistem MIMO MC-DSSS dengan Convolutional Code memiliki unjuk kerja yang lebih baik dari pada sistem MIMO MC-DSSS Uncode pada kanal transmisi Rayleigh Fading. Hal ini disebabkan karena dengan penambahan Convolutional Code terdapat bit redundancy (bit tambahan) yang ditambahkan ke dalam data yang akan ditransmisikan agar menjaga data dari error yang mungkin terjadi selama proses transmisi.
Berdasarkan hasil simulasi dan pembahasan yang telah dilakukan maka diperoleh beberapa kesimpulan diantaranya sebagai berikut:

1. Pada unjuk kerja sistem MIMO MC-DSSS Uncode, kanal transmisi AWGN memiliki nilai BER yang lebih rendah dari kanal transmisi Rayleigh Fading. Untuk mencapi nilai BER sebesar $10^{-3}$ pada kanal transmisi AWGN dibutuhkan Eb/No sebesar -4 dB. Sedangkan pada kanal transmisi Rayleigh Fading dibutuhkan Eb/No sebesar $-3 \mathrm{~dB}$.

2. Pada unjuk kerja sistem MIMO MC-DSSS dengan Convolutional Code, kanal transmisi AWGN memiliki nilai BER yang lebih rendah dari kanal transmisi Rayleigh Fading. Untuk mencapi nilai BER sebesar 103 pada kanal transmisi AWGN dibutuhkan Eb/No sebesar -8 dB. Sedangkan pada kanal transmisi Rayleigh Fading dibutuhkan Eb/No sebesar $-7 \mathrm{~dB}$.

3. Pada perbandingan unjuk kerja dari sistem MIMO MCDSSS Uncode dan MIMO MC-DSSS dengan Convolutional Code didapat unjuk kerja dari sistem MIMO MC-DSSS dengan Convolutional Code lebih baik. Pada kanal transmisi Rayleigh Fading untuk mencapi nilai BER sebesar $10^{-3}$ pada sistem MIMO MC-DSSS dengan Convolutional Code dibutuhkan Eb/No sebesar $-7 \mathrm{~dB}$. Sedangkan pada sistem MIMO MC-DSSS dibutuhkan Eb/No sebesar -3 dB.

\section{REFERENSI}

[1] K. Fazel and S. Kaiser, Multi-carrier and Spread Spectrum Systems, 2nd ed., Ericsson GmbH, Germany, DOCOMO Communications Laboratories Europe GmbH: Germany, 2008.

[2] T. B. Purwanto, Analisis Unjuk Kerja Teknik MIMO STBC dan VBlast Pada Sistem Orthogonal Frequency Division Multiplexing, Jurusan Teknik Elektro Fakultas Teknik Universitas Udayana, Bukit Jimbaran: Bali, 2015.

[3] M. L. Hakim, Analisis Kinerja Sistem MIMO-OFDM Pada Kanal Rayleigh dan AWGN Dengan Modulasi QPSK, Teknik Elektro Universitas Diponogoro: Semarang, 2010.

[4] F. J. H. Utomo, Analisis Unjuk Kerja Coded-OFDM Melalui Kanal AWGN dan Rayleigh Fading, Jurusan Teknik Elektro Fakultas Teknik Universitas Udayana, Bukit Jimbaran: Bali, 2015.

[5] N. A. Haryadi, Suwadi, dan T. Suryani, "Implementasi Direct Sequence Spread Spectrum pada DSK TMS320C6416T," JURUSAN TEKNIK POMITS., vol. 3, ISSN. 2337-3539, 2014.

[6] T. B. Purwanto, N. M. A. E. D. Wirastuti, dan I. G. A. K. D. D. Hartawan, "Analisis Unjuk Kerja Teknik MIMO Pada Sistem Orthogonal Frequency Division Multiplexing," E-Journal SPECTRUM., vol. 2, No. 2, Juni 2015.

[7] K. Syahgustina, Simulasi dan Analisa Kinerja Sistem MIMO OFDMFDMA Berdasarkan Alokasi Subcarrier, Fakultas Teknik Program Studi Teknik Elektro Universitas Indonesia: Depok, 2009.

[8] F. L. H. Utomo, N. M. A. E. D. Wirastuti, dan I. G. A. K. D. D. Hartawan, "Analisis Unjuk Kerja Coded OFDM Menggunakan Kode Convolutional Pada Kanal AWGN dan Rayleigh Fading," E-Journal SPECTRUM., vol. 2, No. 2, Juni 2015.

\section{KESIMPULAN}

